\title{
Naked DNA vaccination of Atlantic salmon Salmo salar against IHNV
}

\author{
Garth S. Traxler ${ }^{1, *}$, Eric Anderson ${ }^{2}$, Scott E. LaPatra ${ }^{3}$, Jon Richard ${ }^{1}$, \\ Bill Shewmaker ${ }^{3}$, Gael Kurath ${ }^{4}$
}

\author{
${ }^{1}$ Department of Fisheries and Oceans, Pacific Biological Station, Nanaimo, British Columbia V9R 5K6, Canada \\ ${ }^{2}$ University of Maine, Orono, Maine 04469-5735, USA \\ ${ }^{3}$ Clear Springs Foods, Inc., Buhl, Idaho 83316, USA \\ ${ }^{4}$ Western Fisheries Research Center, Seattle, Washington 98115, USA
}

\begin{abstract}
A naked plasmid DNA encoding the glycoprotein (pCMV4-G) of a 1976 isolate of infectious hematopoietic necrosis virus (IHNV) obtained from steelhead Oncorhynchus mykiss was used to vaccinate Atlantic salmon Salmo salar against IHNV. Eight weeks post-vaccination the fish were challenged with a strain of IHNV originally isolated from farmed Atlantic salmon undergoing an epizootic. Fish injected with the glycoprotein-encoding plasmid were significantly $(p<0.05)$ protected against IHNV by both immersion and cohabitation challenge. Survivors of the first challenges were pooled and re-challenged by immersion $12 \mathrm{wk}$ after the initial challenge. Significant $(p<0.05)$ protection was observed in all of the previously challenged groups including those receiving the complete vaccine. Fish injected with the glycoprotein-encoding plasmid produced low levels of virus-neutralizing antibodies prior to the first challenge. Neutralizing antibodies increased in all groups after exposure to the IHNV. Passive transfer of pooled sera from pCMV4-G vaccinates and IHN survivors provided relative survivals of 40 to $100 \%$ compared to fish injected with sera collected from fish immunized with control vaccines or left unhandled. In this study, DNA vaccination effectively protected Atlantic salmon smolts against challenges with IHNV.
\end{abstract}

KEY WORDS: DNA $\cdot$ Vaccine $\cdot G$ protein $\cdot$ Atlantic salmon $\cdot$ IHNV

\section{INTRODUCTION}

Infectious hematopoietic necrosis virus (IHNV) is enzootic in salmonid species along the Pacific coast of North America. The virus causes significant losses among both wild and cultured fish, usually at the juvenile life stages (Williams \& Amend 1976, Mulcahy et al. 1980, Traxler \& Rankin 1989). However, in intensive culture, losses of larger fish have been reported (Busch 1983). Over the past decade the aquaculture industry in British Columbia, Canada, has grown to produce $36000 \mathrm{t}$ of salmon in 1997 (B.C. Salmon Farmers Assoc.). Atlantic salmon Salmo salar account for $80 \%$ of the total production with chinook Onchorhynchus tshawytscha and coho $O$. kisuch

\footnotetext{
•E-mail: traxlerg@dfo-mpo.gc.ca
}

salmon making up the remaining $20 \%$. In 1992, infectious hematopoietic necrosis (IHN) was diagnosed in Atlantic salmon at a sea pen site on the east coast of Vancouver Island (Armstrong 1993, Traxler et al. 1993). Over the next several years IHNV caused clinical disease in Atlantic salmon at 11 additional sites all within the same geographic region located on the east coast of central Vancouver Island. Losses of penreared Atlantic salmon at affected sites ranged from $20 \%$ in the larger fish (1 to $3 \mathrm{~kg}$ ) up to $80 \%$ in the smaller fish (100 to $300 \mathrm{~g}$ ). The severe economic losses suffered by the fish farming industry due to IHNV has prompted investigations into the development of vaccines to control losses. In British Columbia, autogenous vaccines consisting of killed virus have had limited success in reducing the losses attributed to IHNV. There have been reports of IHNV in vaccinated fish (S. St. Hilarie pers. comm.). 
A new approach to disease prevention in aquaculture has been the application of genetic immunization or DNA-based vaccination (Anderson et al. 1996a, Heppell et al. 1998). The first demonstration of the efficacy of a DNA vaccine in fish was in rainbow trout Oncorhynchus mykiss immunized against IHNV (Anderson et al. 1996b). Subsequently, DNA vaccination studies by Lorenzen et al. (1998) showed protective immunity in rainbow trout when challenged with viral hemorrhagic septicemia virus (VHSV), another important rhabdovirus pathogen of fish. A combined DNA vaccination experiment using VHSV and IHNV glycoprotein was shown to induce a protective antibody response measured by passive immunization (Boudinot et al. 1998).

In this study the efficacy of a DNA vaccine prepared with the gene encoding the IHNV glycoprotein administered to Atlantic salmon pre-smolts and smolts was tested for its ability to prevent IHN in fish challenged by immersion and cohabitation. The aquaculture industry in British Columbia immunizies fish while in fresh water prior to smolting. We were interested in knowing whether genetic DNA vaccination of Atlantic salmon against IHNV was effective when administered before and after seawater entry. Fish were challenged in seawater by cohabitation with IHNV injected fish and by waterborne exposure to IHNV. Survivors of the first challenge were rechallenged by immersion. The humoral immune response prior to and after challenge was determined by measuring the neutralizing antibody activity in serum against IHNV and by determining the protection afforded to naive fish after passive transfer of serum containing neutralizing antibody

\section{MATERIAL AND METHODS}

Cell culture and virus. The epithelioma papillosum cyprinii (EPC) cell line was used for the propagation of IHNV (Fijan et al.1983). The virus used in this study was isolated from clinically infected Atlantic salmon in sea pens in 1992 (Armstrong et al. 1993, Traxler et al. 1993) and confirmed as IHNV by serum neutralization. Infected monolayers were cultured at $15^{\circ} \mathrm{C}$ in minimal essential media supplemented with $10 \%$ fetal bovine serum (Gibco BRL). The virus was passed in cell culture twice, pooled and aliquoted, and stored at $-80^{\circ} \mathrm{C}$ prior to use. Fish dying from challenges were assayed for IHNV by aseptic removal anterior kidney tissue, dilution of the tissue samples 1:10 with Earle's balanced salt solution and homogenizing with a Polytron generator (Brinkman Instruments Co., Rexdale, Ontario, Canada). Homogenates were centrifuged for $10 \mathrm{~min}$ at $2000 \times g$ and 10 -fold dilutions of the super- natants were inoculated on preformed monolayers of EPC cells. The cultures were fixed and stained after 7 to $10 \mathrm{~d}$ incubation at $15^{\circ} \mathrm{C}$. The virus was quantified by counting plaques and titers were calculated as plaque forming units (pfu) $\mathrm{ml}^{-1}$ of fluid or gram of tissue (Burke \& Mulcahy 1980).

DNA preparation. The plasmid DNAs used in this study have been previously described (Anderson et al. 1996a,b). Plasmid pCMV4-G contains the complete IHNV glycoprotein cDNA of a 1976 isolate fused to the human cytomegalovirus immediate early promoter (hCMV-IEP) and pCMVL contains the firefly Photinus pyralis luciferase cDNA adjacent to the hCMV-IEP.

The plasmids were grown in Escherichia coli DH $5 \alpha$ at $37^{\circ} \mathrm{C}$ with Luria-Bertani broth and agar plates supplemented with $50 \mathrm{mg} \mathrm{ml}^{-1}$ ampicillin (Sambrook et al. 1989). The plasmids used for vaccination were prepared from $250 \mathrm{ml}$ overnight cultures using an ammonium acetate purification protocol (Saporito-Irwin et al. 1997). The purified DNAs were stored in $10 \mathrm{mM}$ Tris, $1 \mathrm{mM}$ EDTA, $\mathrm{pH} 7.4$, at $2 \mathrm{mg} \mathrm{ml}^{-1}$. For vaccination DNA was diluted to $250 \mu \mathrm{ml}^{-1}$ in PBS $(0.14 \mathrm{M}$ sodium chloride, $10 \mathrm{mM}$ sodium phosphate, $\mathrm{pH}$ 7.4).

Fish. Atlantic salmon (Mowi strain) were moved from a hatchery with no previous occurrence of IHN to the Pacific Biological Station, Nanaimo, British Columbia. Fish were held in $9^{\circ} \mathrm{C}$ pathogen-free fresh water for 2 wk to acclimate. The fish were then randomly divided into 2 lots; one group was acclimated to seawater (smolted) by increasing the seawater:freshwater ratio by $1 / 4$ every 4 to $5 \mathrm{~d}$, the other group remained in fresh water.

Vaccination. Two weeks after the first group of Atlantic salmon was smolted, both groups were vaccinated and moved to the quarantine laboratory where all subsequent vaccination and challenge experiments were conducted at $10^{\circ} \mathrm{C}$. Both groups of Atlantic salmon, pre-smolts (mean weight, $57 \mathrm{~g}$ ) and smolts (mean weight, $73 \mathrm{~g}$ ), were anesthetized in $100 \mu \mathrm{g} \mathrm{l}^{-1}$ of tricaine methane sulfonate and injected immediately anterior to the dorsal fin with $100 \mu l$ PBS containing $25 \mu \mathrm{g}$ of DNA (Anderson \& Leong 1999). Four groups of 180 pre-smolts and 4 groups of 130 smolts were placed in eight $750 \mathrm{l}$ tanks supplied with flowing fresh and seawater, respectively. In each group of smolts and pre-smolts there were 4 sub-groups including a pCMV4-G-injected group, and 3 negative control groups including a pCMVL (luciferase)injected group, a PBS (phosphate buffered saline)injected group, and an uninjected group. After 4 wk the 4 groups of pre-smolts were also acclimated to seawater using the same procedure previously described. The group receiving the vaccine prior to smoltification was designated pre-smolts and those receiving the vaccine after smoltification were desig- 
nated as smolts. Both groups of fish were challenged 8 wk post-vaccination.

Challenge protocol. The first virus challenges of each of the 4 groups of pre-smolts and smolts were conducted in duplicate by cohabitation and bath exposure. Groups of 50 pre-smolts or 40 smolts were placed in $750 \mathrm{l}$ tanks supplied with $51 \mathrm{~min}^{-1}$ of flowing water Ten untreated fish from the same stock were injected with $4.9 \times 10^{3} \mathrm{pfu}$ of IHNV, marked by clipping the adipose fin and placed in each of the 16 tanks. For the immersion challenge 20 fish from each treatment were challenged in duplicate by immersion in $20 \mathrm{l}$ of aerated seawater for $1 \mathrm{~h}$. The initial viral titer of the challenge suspension was $5.9 \times 10^{3} \mathrm{pfu} \mathrm{m}^{-1}$, which decreased to $4.6 \times 10^{3} \mathrm{pfu} \mathrm{ml}^{-1}$ after $1 \mathrm{~h}$. All groups of fish challenged by immersion were held in $50 \mathrm{l}$ tanks supplied with flowing water at $2 \mathrm{l} \mathrm{min}^{-1}$. The fish were fed a commercial ration and dead fish were removed daily. Cumulative percent mortality, mean days to death and relative percent survival were calculated for each group.

Ten weeks after the first challenge, surviving fish were anesthetized, marked with numbered operculum tags and bled by caudal peduncle puncture to obtain serum. Fish were then pooled according to whether they were initially challenged by bath or by cohabitation, and whether they were immunized as pre-smolts or smolts. An effort was made to equalize the number of fish contributed from each group. A similar number of naive fish from the original stock that had not been immunized or challenged was added to each group prior to challenge to serve as controls. At $12 \mathrm{wk}$ after the initial challenge, each of the 4 groups (presmolts/immersion, pre-smolts/cohabitation, smolts/immersion and smolts/cohabitation) were re-challenged by bath exposure to $5 \times 10^{4} \mathrm{pfu} \mathrm{ml}^{-1}$ of IHNV for $1 \mathrm{~h}$. The fish were placed in $750 \mathrm{l}$ tanks supplied with $5 \mathrm{l}$ $\mathrm{min}^{-1}$ flowing seawater at $10^{\circ} \mathrm{C}$. Each day for $30 \mathrm{~d}$, fish were fed and mortalities were removed and recorded. For both challenges, accumulated mortalities were recorded and random samples were examined virologically, except for fish receiving the pCMV4-G vaccine where all dead fish were assayed for the titer of IHNV present in the internal tissues. Cumulative percent mortality of the replicate tanks from the first challenge and the re-challenged groups was analyzed by analy-

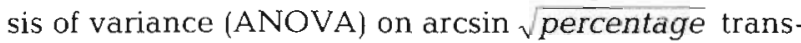
formed data (Snedecor \& Cochran 1967).

Neutralizing antibody. Fish were bled and serum was collected from representative numbers of fish prior to vaccination and from fish at $8 \mathrm{wk}$ post-vaccination just prior to exposure to IHNV. Survivors of the first challenge experiment were also bled for serum collection and marked, with numbered operculum tags, prior to the second challenge. Sera was also collected from the survivors of the second challenge. The presence and titer of neutralizing antibodies was determined using a plaque reduction method (LaPatra et al. 1993). Two-fold serial dilutions of each serum sample in Hanks' balanced salt solution were tested for neutralizing activity by reacting with a standard amount of IHN virus for $1 \mathrm{~h}$ at $17^{\circ} \mathrm{C}$. Complement in unheated serum collected from disease-free rainbow trout was added to test wells and allowed to incubate an additional $1 \mathrm{~h}$ at $17^{\circ} \mathrm{C}$. The antibody titer was reported as the reciprocal of the highest dilution that resulted in a $50 \%$ reduction in the average number of plaques when compared to the negative controls.

Passive immunization. Serum collected from groups of unhandled, pre-immune, vaccinated and from vaccinated survivors with detectable and non-detectable neutralizing activity was pooled by treatment group. For passive immunization tests, rainbow trout (mean weight, $1 \mathrm{~g})$ were anesthetized and injected intraperitoneally with $50 \mu \mathrm{l}$ of test or control serum. Groups of 25 fish were challenged in duplicate with $10^{4} \mathrm{pfu} \mathrm{ml^{-1 }}$ by standard procedures $24 \mathrm{~h}$ after passive transfer (LaPatra et al. 1994b). At least $20 \%$ of the fish that died on any given day were tested for virus. Quantification of virus used in the challenge or isolated from dead fish was performed by plaque assay procedures previously described (LaPatra et al. 1991). The mean cumulative percent mortality of each group was calculated. Comparisons between treatments were made on replicates by ANOVA on transformed data.

\section{RESULTS}

\section{First challenge}

When fish were challenged $8 \mathrm{wk}$ after vaccination, a significant $(p<0.05)$ level of protection was seen in all groups receiving the vaccine containing the pCMV4-G plasmid (Table 1). The groups of fish injected with pCMVL and PBS also showed some increased but not significant survival when compared to the uninjected groups; however, this survival was considerably less than that observed in the pCMV4-G-vaccinated groups. Among all of the different groups exposed to IHNV, only $5 / 260$ fish receiving the pCMV4-G plasmid died. Losses in the immersion challenged fish began at 7 to $9 \mathrm{~d}$ post-exposure, while those in the cohabitation challenged groups began 15 to $21 \mathrm{~d}$ post-exposure. Injected fish serving as a source of virus in the cohabitation experiments began dying 4 to $7 \mathrm{~d}$ post-injection and the mean time to death for the injected groups was $19 \mathrm{~d}$. Virus was detected in $93 \%(141 / 152)$ of the dead Atlantic salmon examined. Virus concentrations determined on these fish were all $\geq 10^{4} \mathrm{pfu}^{-1}$ of tissue. 
Table 1. Salmo salar. Mortality of Atlantic salmon challenged with IHN virus 8 wk post-vaccination. RPS: relative percent survival

\begin{tabular}{|c|c|c|c|c|c|c|c|}
\hline \multirow[t]{2}{*}{ Treatment } & \multicolumn{2}{|c|}{ No. of fish } & \multicolumn{2}{|c|}{ Percent mortality } & \multicolumn{2}{|c|}{ Mean days to death } & \multirow[t]{2}{*}{ RPS $^{\circ}$} \\
\hline & Tank 1 & Tank 2 & Tank 1 & Tank 2 & Tank 1 & Tank 2 & \\
\hline \multicolumn{8}{|l|}{ Immersion $^{b}$} \\
\hline Pre-smolts uninjected & 20 & 20 & 70 & 65 & 22 & 19 & - \\
\hline Pre-smolts pbs & 20 & 20 & 35 & 55 & 23 & 18 & 34 \\
\hline Pre-smolts pCMV-L & 20 & 20 & 45 & 55 & 24 & 27 & 26 \\
\hline Pre-smolts pCMV4-G' & 20 & 20 & 0 & 5 & - & 14 & 96 \\
\hline \multicolumn{8}{|l|}{ Cohabitation $^{c}$} \\
\hline Pre-smolts uninjected & 50 & 50 & 44 & 38 & 43 & 45 & - \\
\hline Pre-smolts pbs & 50 & 50 & 20 & 32 & 44 & 40 & 37 \\
\hline Pre-smolts pCMV-L & 50 & 50 & 20 & 32 & 41 & 40 & 37 \\
\hline Pre-smolts pCMV4-G' & 50 & 50 & 0 & 0 & - & - & 100 \\
\hline \multicolumn{8}{|l|}{ Immersion } \\
\hline Smolts uninjected & 20 & 20 & 50 & 50 & 20 & 21 & - \\
\hline Smolts pbs & 20 & 20 & 55 & 45 & 30 & 38 & 0 \\
\hline Smolts pCMV-L & 20 & 20 & 30 & 40 & 24 & 32 & 30 \\
\hline Smolts pCMV4-G' & 20 & 20 & 5 & 5 & 20 & 18 & 90 \\
\hline \multicolumn{8}{|l|}{ Cohabitation } \\
\hline Smolts uninjected & 40 & 40 & 28 & 45 & 47 & 45 & - \\
\hline Smolts pbs & 40 & 40 & 43 & 28 & 35 & 34 & 3 \\
\hline Smolts pCMV-L & 40 & 40 & 30 & 28 & 35 & 38 & 19 \\
\hline Smolts pCMV4-G' & 40 & 40 & 3 & 3 & 33 & 72 & 93 \\
\hline \multicolumn{8}{|c|}{${ }^{\mathrm{a}} \mathrm{RPS}=1-\left(\frac{\text { cumulative } \% \text { mortality of vaccinated fish }}{\text { cumulative } \%}\right)$} \\
\hline \multicolumn{8}{|c|}{${ }^{b}$ Fish challenged by immersion were exposed to $5.9 \times 10^{3}$ plaque forming units (pfu) $\mathrm{ml}^{-1}$ for $1 \mathrm{~h}$} \\
\hline \multicolumn{8}{|c|}{${ }^{c}$ Fish were challenged by cohabitation by adding 10 fish injected with $4.9 \times 10^{3}$ pfu of IHN virus to each tank } \\
\hline - Significantly different $\mathrm{fr}$ & all other & ups $(p<$ & & & & & \\
\hline
\end{tabular}

\section{Second challenge}

Surviving fish from the first challenges, both by immersion and cohabitation, were significantly protected compared to naive fish from the original stock when exposed to a high concentration of IHNV by bath. In this study, the fish that were exposed to $5 \times 10^{4}$ pfu ml $\mathrm{m}^{-1}$ of IHNV for $1 \mathrm{~h}$, a dose that killed 80 to $95 \%$ of the control fish, resulted in a loss of $5 \%$ or less of the fish vaccinated with $\mathrm{pCMV4-G}$. The losses among the other control groups that had been exposed to IHN virus from either immersion or cohabitation ranged from $0 \%$, in a pCMVL-vaccinated group, to $15 \%$ in an uninjected group (Table 2). Virus was detected in $97 \%$ $(67 / 70)$ of the dead Atlantic salmon examined. No virus was detected in 30 fish surviving the second immersion challenge.

\section{Neutralizing antibodies}

Specific IHNV neutralizing antibodies were determined from representative fish from each group $8 \mathrm{wk}$ post-vaccination. Only the group injected with the pCMV4-G vaccine developed virus-neutralizing anti- body (Table 3). Serum collected from smolts and presmolts $8 \mathrm{wk}$ post-immunization with pCMV4-G had a seroprevalence of $44 \%$ (4/9) and $27 \%$ (4/15) and mean titers of $<20$ and $<10$, respectively. After challenge by immersion or cohabitation all groups of pre-smolts and smolts developed a high frequency of seropositive fish. Neutralizing titers were high in the seropositive fish after challenge with over half of the fish having titers of 160 or higher.

\section{Passive immunization}

Passive immunization of rainbow trout with serum from Atlantic salmon immunized with pCMV4G provided some protection against IHNV challenge (Table 4). Rainbow trout immunized with serum from Atlantic salmon receiving the glycoprotein vaccine exhibited a cumulative mortality of $30 \%(15 / 50)$ compared to 48 to $60 \%$ of the fish receiving serum from unhandled and other control groups. Rainbow trout injected with serum obtained from surviving Atlantic salmon of a cohabitation challenge with IHN virus showed significant $(p<0.05)$ protection. Fish passively immunized with serum from Atlantic salmon exhibit- 
Table 2. Salmo salar. Mortality of Atlantic salmon survivors re-challenged by immersion in seawater containing $5 \times 10^{4}$ plaque forming units (pfu) $\mathrm{ml}^{-1}$ for $1 \mathrm{~h}, 12 \mathrm{wk}$ after initial challenge. Naive groups were fish from the original stock that had not been previously immunized or challenged. RPS: relative percent survival; ns: not sampled. Number in parentheses in final volumes indicates number of fish

\begin{tabular}{|c|c|c|c|c|c|}
\hline \multirow[t]{2}{*}{ Treatment } & \multirow[t]{2}{*}{$\begin{array}{l}\text { No. of deaths/ } \\
\text { total no. }\end{array}$} & \multirow[t]{2}{*}{$\begin{array}{l}\text { Percent } \\
\text { mortality }\end{array}$} & \multirow[t]{2}{*}{$\mathrm{RPS}^{\mathrm{a}}$} & \multicolumn{2}{|c|}{$\begin{array}{l}\text { IHNV neutralization titers of } \\
\text { fish that died after re-challenge }\end{array}$} \\
\hline & & & & No. of fish & Antibody titer \\
\hline \multicolumn{6}{|l|}{ Tank 1: Immersion } \\
\hline Naive & $19 / 20$ & 95 & - & & $-{ }^{c}$ \\
\hline Pre-smolts uninjected & $1 / 9$ & 11 & 88 & 1 & $\geq 160$ \\
\hline Pre-smolts PBS & $2 / 18$ & 11 & 88 & 2 & $\geq 160$ \\
\hline Pre-smolts pCMV-L & $2 / 17$ & 12 & 87 & 2 & $<20$ \\
\hline Pre-smolts pCMV4-G & $0 / 21$ & 0 & 100 & 0 & - \\
\hline \multicolumn{6}{|l|}{ Tank 2: Cohabitation } \\
\hline Naive & $36 / 40$ & 90 & - & & \\
\hline Pre-smolts uninjected & $6 / 39$ & 15 & 83 & 6 & $(4)<20,40, \geq 160$ \\
\hline Pre-smolts PBS & $6 / 39$ & 15 & 83 & 6 & $<20,40,(4) \geq 160$ \\
\hline Pre-smolts pCMV-L & $0 / 40$ & 0 & 100 & 0 & - \\
\hline Pre-smolts pCMV4-G ${ }^{*}$ & $1 / 38$ & 3 & 97 & 1 & 20 \\
\hline \multicolumn{6}{|l|}{ Tank 3: Immersion } \\
\hline Naive & $16 / 20$ & 80 & - & & \\
\hline Smolts uninjected & $1 / 19$ & 5 & 94 & 1 & $\geq 160$ \\
\hline Smolts PBS & $1 / 16$ & 6 & 92 & 1 & 40 \\
\hline Smolts pCMV-L & $0 / 19$ & 0 & 100 & 0 & - \\
\hline Smolts pCMV4-G' & $0 / 21$ & 0 & 100 & 0 & - \\
\hline \multicolumn{6}{|l|}{ Tank 4: Cohabitation } \\
\hline Naive & $34 / 40$ & 85 & - & & \\
\hline Smolts unhandled & $4 / 39$ & 10 & 88 & 4 & ns, $(3) \geq 160$ \\
\hline Smolts PBS & $4 / 40$ & 10 & 88 & 4 & $(2)<20,(2) \geq 160$ \\
\hline Smolts pCMV-L & $4 / 40$ & 10 & 88 & 4 & (2) 80, (2) $\geq 160$ \\
\hline Smolts pCMV4-G' & $2 / 39$ & 5 & 94 & 2 & ns, $\geq 160$ \\
\hline \multicolumn{6}{|c|}{ RPS $=1-\left(\frac{\text { cumulative } \% \text { mortality of vaccinated fish }}{\text { cumulative } \% \text { mortality of control fish }}\right)$} \\
\hline \multicolumn{6}{|c|}{$\begin{array}{l}\text { b Neutralizing titers were determined by sampling fish prior to challenge. The titer indicates the reciprocal of the highest dilu } \\
\text { tion that resulted in a } 50 \% \text { reduction in the number of plaques detected in the negative control wells }\end{array}$} \\
\hline \multicolumn{6}{|c|}{${ }^{\mathrm{C} A n t i b o d y}$ titers of 30 naive fish tested prior to challenge were all $<20$} \\
\hline \multicolumn{6}{|c|}{ - Significantly different from all other groups $(p<0.05)$} \\
\hline
\end{tabular}

ing low neutralizing activity (titer, 20) exhibited a combined mortality of $10 \%(5 / 52)$, whereas those receiving serum with high neutralizing activity (titer $\geq 160$ ) were completely protected. Among the groups of rainbow trout challenged with IHNV, virus was recovered from $91 \%(78 / 86)$ of the dead fish that were examined. The mean IHNV concentration was $10^{6.7} \mathrm{pfu} \mathrm{g}^{-1}$ (range $10^{2.9}$ to $>10^{7.3}$ ) in combined liver-spleen-kidney samples.

\section{DISCUSSION}

Viral diseases of fish have to date been controlled by avoidance including the use of virus-free water supplies, broodstock screening and selection, and iodophor disinfection of eggs. In the aquaculture industry, where fish are raised under intensive culture conditions, the opportunity to immunize fish by vaccination has led to the development of several commercially available vaccines. Atlantic salmon introduced to British Columbia in 1985 for aquaculture, now represents the main species of salmon grown by salmon farmers. Atlantic salmon, at all sizes, appear highly susceptible to IHN virus and the industry has experienced severe economic losses. As previously mentioned, numerous IHN injectable vaccines have been developed and tested with limited success, including recently, the use of killed autogenous IHNV vaccine at several net pen sites in the area of British Columbia experiencing the most severe losses to IHN. The promising results of DNA vaccines developed against the rhabdoviruses VHSV and IHNV, when tested in rainbow trout fry, prompted this investigation into the efficacy of the technology when applied to larger Atlantic salmon pre-smolts and smolts. 
Table 3. Salmo salar. IHN virus neutralizing antibodies present in Atlantic salmon at $8 \mathrm{wk}$ post-vaccination (prior to challenge) and $12 \mathrm{wk}$ after challenge by immersion or cohabitation

\begin{tabular}{|c|c|c|c|}
\hline Treatment & $\begin{array}{l}\text { No. positive/ } \\
\text { no. tested }\end{array}$ & $\begin{array}{l}\text { Percent } \\
\text { positive }\end{array}$ & $\begin{array}{l}\text { Neutralizing titer } \\
\text { mean/range }\end{array}$ \\
\hline \multicolumn{4}{|c|}{$8 \mathrm{wk}$ post vaccination, prior to challenge } \\
\hline Uninjected & $0 / 23$ & 0 & 0 \\
\hline PBS & $0 / 21$ & 0 & 0 \\
\hline pCMV-L & $0 / 18$ & 0 & 0 \\
\hline pCMV4-G & $8 / 24$ & 33 & $11 / 0-80$ \\
\hline \multicolumn{4}{|c|}{12 wk post-challenge pre-smolts/immersion challenge } \\
\hline Pre-smolts uninjected & $14 / 14$ & 100 & $160 / 160$ \\
\hline Pre-smolts PBS & $19 / 21$ & 90 & $138 / 0-160$ \\
\hline Pre-smolts pCMV-L & $17 / 19$ & 89 & $133 / 0-160$ \\
\hline Pre-smolts pCMV4-G & $19 / 22$ & 86 & $131 / 0-160$ \\
\hline \multicolumn{4}{|c|}{12 wk post-challenge pre-smolts/cohabitation challenge } \\
\hline Pre-smolts uninjected & $28 / 42$ & 66 & $97 / 0-160$ \\
\hline Pre-smolts PBS & $29 / 42$ & 69 & $95 / 0-160$ \\
\hline Pre-smolts pCMV-L & $36 / 42$ & 86 & $124 / 0-160$ \\
\hline Pre-smolts pCMV4-G & $37 / 42$ & 88 & $104 / 0-160$ \\
\hline \multicolumn{4}{|c|}{12 wk post-challenge smolts/immersion challenge } \\
\hline Smolts unhandled & $17 / 20$ & 85 & $115 / 0-160$ \\
\hline Smolts PBS & $17 / 19$ & 84 & $136 / 0-160$ \\
\hline Smolts pCMV-L & $20 / 22$ & 91 & $138 / 0-160$ \\
\hline Smolts pCMV4-G & $19 / 22$ & 86 & $118 / 0-160$ \\
\hline \multicolumn{4}{|c|}{$12 \mathrm{wk}$ post-challenge smolts/cohabitation challenge } \\
\hline Smolts unhandled & $30 / 42$ & 72 & $104 / 0-160$ \\
\hline Smolts PBS & $31 / 42$ & 73 & $108 / 0-160$ \\
\hline Smolts pCMV-L & $35 / 42$ & 83 & $117 / 0-160$ \\
\hline Smolts pCMV4-G & $37 / 42$ & 88 & $119 / 0-160$ \\
\hline \multicolumn{4}{|c|}{$\begin{array}{l}\text { aNeutralizing titer indicates the reciprocal of the highest dilution that } \\
\text { resulted in a } 50 \% \text { reduction in the number of plaques detected in } \\
\text { the negative control wells. Upper detection limits were dilutions of } \\
160 ; \text { means were calculated using values of } 160 \text { when upper detec- } \\
\text { tion limits were exceeded }\end{array}$} \\
\hline
\end{tabular}

Recent studies have revealed that DNA vaccine amounts of $1 \mu \mathrm{g}$ effectively protect rainbow trout against IHNV (Corbeil et al. unpubl.). Thus future work will focus on determining the minimum effective dose needed to confer protection so as to minimize both the potential safety risks and cost associated with the DNA vaccine.

Protection of DNA vaccinated fish was observed when fish were exposed to the virus in high levels for short duration by waterborne challenges or by exposure to low levels of virus over a long period of time by cohabitation with infected fish. The latter challenge method was designed to more accurately simulate the conditions found in sea cages prior to an IHN epizootic. Importantly, we found no significant difference in relative percent survival of fish vaccinated as pre or post-smolts when challenged with the virus in seawater using either method. Thus the physiological stress of smoltification (Maule et al. 1987) appears not to diminish the efficacy of the DNA vaccine.

Fish can be exposed to IHNV throughout their life cycle. Because of this there is concern that DNA vaccinated fish after recovering from an IHN challenge could become subclinical carriers (Amend 1975, Drolet et al. 1994) and thus be a source of IHNV shedding or be more susceptible to IHN upon re-exposure. When survivors of the first challenge were again exposed to virus, the DNA-vaccinated groups were protected to the same degree as mock vaccinated virus-exposed Atlantic salmon. We tested survivors of the second challenge from all treatment groups,
This study demonstrates that a single intramuscular injection of Atlantic salmon with $25 \mu \mathrm{g}$ DNA vaccine $\mathrm{pCMV}-\mathrm{G}$ results in significant protection against an IHNV challenge. The quantity of vaccine used and vaccination method was based on in vivo challenge studies using rainbow trout (mean weight <15 g) (Anderson et al. 1996b, Lorenzen et al. 1998). The results extend the findings of earlier studies and demonstrate that viral DNA vaccines are effective in larger size fish (70 to $80 \mathrm{~g})$ and that Atlantic salmon, another economically important farmed fish species, can be included in the species that elicit a protective immune response following injection with a DNA vaccine.
Table 4. Oncorhynchus mykiss. Mortality of rainbow trout fry after passive immunization with $50 \mu \mathrm{l}$ of Atlantic salmon sera from groups after vaccination and after surviving an IHNV cohabitation challenge. Replicate groups of $25 \mathrm{fish}$ (mean weight, $1 \mathrm{~g}$ ) were challenged with $10^{4}$ plaque forming units $\mathrm{ml}^{-1}$ IHNV for $1 \mathrm{~h}$

\begin{tabular}{|c|c|c|c|c|}
\hline \multirow[t]{2}{*}{ Treatment } & \multicolumn{2}{|c|}{ Cumulative mortality } & \multirow{2}{*}{$\begin{array}{l}\text { Mean percent } \\
\text { mortality }\end{array}$} & \multirow{2}{*}{$\begin{array}{l}\text { Pooled sera } \\
\text { titer }\end{array}$} \\
\hline & Tank 1 & Tank 2 & & \\
\hline Unhandled & $12 / 25$ & $12 / 25$ & 48 & $<20$ \\
\hline Pre-immune serum & $12 / 26$ & $13 / 24$ & 50 & $<20$ \\
\hline PBS & $11 / 23$ & $16 / 24$ & 57 & $<20$ \\
\hline pCMV-L & $14 / 26$ & $16 / 24$ & 60 & $<20$ \\
\hline pCMV4-G & $9 / 25$ & $6 / 25$ & 30 & $<20$ \\
\hline Low titer survivors ${ }^{*}$ & $3 / 26$ & $2 / 26$ & 10 & 20 \\
\hline High titer survivors" & $0 / 23$ & $0 / 25$ & 0 & 160 \\
\hline \multicolumn{5}{|c|}{ - Significantly different from all other groups $(p<0.05)$} \\
\hline
\end{tabular}


including the DNA-vaccinated fish, for virus by standard cell culture methods and found no evidence of infectious virus (data not shown). It is possible that the use of more sensitive IHNV detection methods would reveal the presence of latent viral infection (Drolet et al. 1995). However, given that infectious virus was not present in the DNA vaccinated survivors and that they were also significantly protected upon re-exposure to IHNV, there is reason to believe that the DNA vaccine did not result in establishment of a carrier state.

The IHNV G protein has been shown to be the only viral protein capable of eliciting neutralizing antibodies and stimulating protective immunity in young fish (Engleking \& Leong 1989). However, in recent years there appears to be increasing serological variation among IHNV isolates (LaPatra et al. 1994a). The pCMV-G vaccine used in this study has the $G$ gene from a 1976 isolate obtained from steelhead Oncorhynchus mykiss from the Deschutes River in Oregon, USA. Although this isolate is temporally and geographically distinct from the more recent isolate obtained from large sea pen-reared Atlantic salmon, the vaccine was still able to confer significant protection. This supports previous results that indicated that fish serum with neutralizing activity that protected against one antigentic variant of IHNV would crossprotect against the antigenic variants and that a vaccine against a single type of IHNV may be efficacious against all IHNV isolates (LaPatra et al. 1994a).

In this study, there was a slight trend in fish vaccinated with $p C M V-G$ to seroconvert at a greater prevalence after being challenged with IHNV compared to the other treatment groups. Although this observation was not consistent in the 4 challenges that evaluated pre-smolts and smolts by immersion and cohabitation challenges, it did suggest that the pCMV-G vaccine may potentially enhance seroconversion. Similar results have been observed using other DNA vaccine model systems including vaccines for lyssaviruses (Bahloul et al. 1997), avian influenza (Fynan et al. 1993) bovine herpesvirus 1 (Cox et al. 1993), and human immumodeficiency virus type 1 (Wang 1993). In these studies it was shown that the DNA vaccine primed an antibody response that was dose and booster dependent. Further, in the absence of neutralizing antibody the challenge virus was responsible for complete seroconversion. If a similar mechanism occurs with pCMV$G$ vaccinated fish, it will be interesting to determine the rate at which seroconversion occurs following virus exposure. The mechanism would require rapid priming and seroconversion since IHNV results in systemic infection that leads to mortality as early as $5 \mathrm{~d}$ after viral exposure (Drolet et al. 1995). The low seroconversion but significant immunoprotection could also indicate that the DNA vaccine elicited antigen-specific cel- lular immunity or non-specific anti-viral factors that were responsible for conferring protection at early stages of viral infection (Bahloul et al. 1997, Krieg et al. 1998, Whitton et al. 1999).

Previous studies have also shown that passive transfer of serum from jurenile or adult rainbow trout and sockeye salmon with detectable IHNV neutralization activity and titers as low as 20 provides significant protection for rainbow trout against waterborne challenges compared to that of serum from naive groups injected with saline or from fish left unhandled (LaPatra et al. 1993, 1994b, Traxler et al. 1997). Pooling of sera from all 24 pre-smolts and smolts sampled at $8 \mathrm{wk}$ post-immunization with pCMV-G, so that a large volume of serum for the passive transfer studies could be attained, resulted in a neutralization titer below detectable limits $(<20)$. However, relative survivals of 38 to $50 \%$ were consistently observed compared to control groups. Possible explanations include the presence of virus-neutralizing activity below detectable limits and/or the presence of other factors within the serum that enhanced or provided for a protective immune response (Bachman et al. 1997). Although the overall seroprevalence in $\mathrm{pCMV}-\mathrm{G}$ vaccinated fish prior to challenge was only $33 \%$ with a mean titer of approximately 10 , significant protection was observed and almost $90 \%$ of the surviving fish seroconverted. Future studies will attempt to define the mechanism of protection provided by this DNA vaccine for enhancement of the efficacy of this potent biologic.

Acknowledgements. We thank T. P. T. Evelyn for critical review of the manuscript and NorAm Aquaculture Inc. for providing the Atlantic salmon used in this study

\section{LITERATURE CITED}

Amend DF (1975) Detection and transmission of infectious hematopoietic necrosis virus in rainbow trout. J Wildl Dis $11: 471-478$

Anderson E, Leong JC (1999) Development of DNA vaccines for salmonid fish. In: Lowrie DB, Whalen R (eds) Methods in molecular medicine, Vol. 29. DNA vaccines: methods and protocols. Humana Press Inc, Totowa, NJ, p 105-121

Anderson ED, Mourich DV, Leong JC (1996a) Gene expression in rainbow trout (Oncorhynchus mykiss) following intramuscular injection of DNA. Mol Mar Biol Biotechnol 5:105-113

Anderson ED, Mourich DV, Fahrenkrug SC, LaPatra S, Shepherd J, Leong JC (1996b) Genetic immunization of rainbow trout (Oncorhynchus mykiss) against infectious hematopoietic necrosis virus. Mol Mar Biol Biotechnol 5 $114-122$

Armstrong R, Robinson J, Rymes C, Needham T (1993) Infectious hematopoietic necrosis in Atlantic salmon in British Columbia. Can Vet J 34:312-313

Bachman MF, Kalinke U, Athage A, Freer G, Burkhart C Roost HP, Aguet M, Hengartner H, Zinkernagel RM (1997) The role of antibody concentration and avidity in antiviral protection. Science 276:2024-2027 
Bahloul C, Jacob Y, Tordo N, Perrin P (1997) DNA based immunization for exploring the enlargement of immunological cross-reactivity against lyssaviruses. Vaccine 16:417-425

Boudinot P, Blanco M, deKinklin P, Benmansour A (1998) Combined DNA immunization with the gylcoprotein gene of viral hemorrhagic septicemia virus and infectious hematopoietic necrosis virus induces double-specific protective immunity and nonspecific response in rainbow trout. Virology 249:297-306

Burke J, Mulcahy D (1980) Plaquing procedure for infectious hematopoietic necrosis virus. Appl Environ Microbiol 39: 872-876

Busch RA (1983) Viral disease considerations in the commercial trout industry in Idaho. In: Leong JC, Barila TY (eds) Workshop on viral diseases of salmonid fishes in the Columbia River basin. Special Publication, Bonniville Power Administration, Portland, OR, p 84-100

Cox GJM, Zamb TJ, Babiuk LA (1993) Bovine herpesvirus 1: immune responses in mice and cattle injected with plasmid DNA. J Virol 67:5664-5667

Drolet BS, Rohovec JS, Leong JC (1994) The route of entry and progression of infectious hematopoietic necrosis virus in Onchorynchus mykiss (Walbaum): a sequential immunohistochemical study. J Fish Dis 17:337-347

Drolet BS, Chious PP, Heidel J, Leong JC (1995) Detection of truncated virus particles in a persistent RNA virus infection in vivo. Virology 69:2140-2147

Engelking HM, Leong JC (1989) The glycoprotein of infectious hematopoietic necrosis virus elicts neutralizing antibody and protective response. Virus Res 13:213-230

Fijan N, Sulimanovic D, Bearotti M, Musinie D, Zwillenberg LD, Chilmonczyk S, Vantherot JF, deKinkilin P (1983) Some properties of the Epithelioma papulosum cyprinii (EPC) cell line from carp Cyprinus carpio. Ann Virol 134: $207-220$

Fynan EF, Webster RG, Fuller DH, Haynes JR, Santoro JC, Robinson HL (1993) DNA vaccines, protective immunizations by parenteral, mucosal, and gene-gun inoculations. Proc Natl Acad Sci USA 90:11278-11482

Hepell J, Lorenzen N, Armstrong NK, Wu T, Lorenzen E, Einer-Jensen K, Schorr J, Davis HL (1998) Development of DNA vaccines for fish: vector design, intramuscular injection and antigen expression using viral haemorrhagic septicemia virus genes as model. Fish Shellfish Immunol 8: $271-286$

Krieg AM, Yi AK, Schorr J, Davis HL (1998) The role of CpG dinucleotides in DNA vaccines. Trends Microbiol 6:23-27

LaPatra SE, Lauda KA, Morton AW (1991) Antigenic and virulence comparison of eight isolates of infectious hematopoietic necrosis virus from the Hagerman Valley, Idaho, USA. In: Fryer JL (ed) Proceedings of the second international symposium on viruses of lower vertebrates. Oregon State University Press, Corvallis, p 125-129

LaPatra SE, Turner T, Lauda TA, Jones GR, Walker S (1993)

Editorial responsibility: Jo-Ann Leong,

Corvallis, Oregon, USA
Characterization of the humoral response of rainbow trout to infectious hematopoietic necrosis virus. J Aquat Anim Health 5:165-171

LaPatra SE, Lauda KA. Jones GR (1994a) Antigenic variants of infectious hematopoietic necrosis virus and implications for vaccine development. Dis Aquat Org 20:119-126

LaPatra SE, Lauda KA, Jones GR, Walker SC, Shewmaker WD (1994b) Development of passive immunotherapy for control of infectious hematopoietic necrosis. Dis Aquat Org 20:1-6

Lorenzen N, Lorenzen E, Einer-Jensen K, Heppell J, Wu T, Davis $H$ (1998) Protective immunity to VHS in rainbow trout (Oncorhynchus mykiss, Walbaum) following DNA vaccination. Fish Shellfish Immunol 8:261-270

Maule AG, Schreck CB, Kattari SL (1987) Changes in the immune system of coho salmon (Oncorhynchus kisutch) during the parr-to-smolt transformation and after implantation of cortisol. Can J Fish Aquat Sci 44:161-166

Mulcahy DM, Tebbit GL, Groberg WJ, McMichael JS, Winton JR, Hedrick RP, Philippon-Fried M, Pilcher KS, Fryer JL (1980) The occurrence and distribution of salmonid viruses in Oregon. ORESU-T-80-004. Oregon State Univ Sea Grant Program, Corvallis, p 1-71

Sambrook J, Fritsch EF, Maniatis T (1989) Molecular cloning: a laboratory manual, 2nd edn. Cold Spring Harbor Laboratory Press, Cold Spring Harbor, NY

Saporito-Irwin SM, Geist RT, Gutman DH (1997). Ammonium acetate protocol for the preparation of plasmid DNA for mammalian cell transfections. BioTechniques 3:424-426

Snedecor GW, Cochran WG (1967) Statistical methods, 6th edn. Iowa State University Press, Ames, IA

Traxler GS, Rankin JB (1989) An infectious hematopoietic necrosis epizootic in sockeye salmon Oncorhynchus nerka in weaver Creek spawning channel, Fraser River system, B.C., Canada. Dis Aquat Org 6:221-226

Traxler GS, Roome JR, Kent ML (1993) Transmission of infectious hematopoietic necrosis virus in sea water. Dis Aquat Org 16:111-114

Traxler GS, Roome JR, Lauda KA, LaPatra S (1997) Appearance of infectious hematopoietic necrosis virus (IHNV) and neutralizing antibodies in sockeye salmon Oncorhynchus nerka during their migration and maturation period. Dis Aquat Org 28:31-38

Wang $B$, Ugden KE, Srikatanan V, Agadjanyan MC, Dang MC, Refaeli Y, Sato AI, Boyes L, Williams WV, Weiner DB (1993) Gene inoculation generates immune responses against human immunodeficiency virus type 1. Proc Natl Acad Sci USA 90:4156-4160

Whitton JL, Rodriquez F, Zhang J, Hassett DE (1999) DNA immunization: mechanistic studies. Vaccine 17:1612-1619

Williams I, Amend DF (1976) A natural epizootic of infectious hematopoietic necrosis in fry of sockeye salmon (Oncorhynchus nerka) at Chilko Lake. British Columbia. J Fish Res Board Can 35:875-879

Submitted: July 18, 1999, Accepted: September 21, 1999

Proofs received from author(s): November 3, 1999 